\title{
Adolescent Knowledge of Anemia and Iron Supplement Consumption Before and After Health Education
}

\author{
Mitra \\ Masters Program of Public Health, Hang Tuah Institute of Health Science, Pekanbaru, \\ Indonesia \\ Email: mitra@htp.ac.id
}

\begin{abstract}
The purpose of this study was to describe adolescent knowledge of iron supplement anemia and consumption before and after health education. This research was quantitative with a quasi-experimental design using pre-posttest without control. The material presented in the form of lectures and videos on 119 students at 16 senior high school in Pekanbaru. Pre and Post-test to evaluate the level of knowledge of adolescents. The results showed that before counseling $35.5 \%$ of adolescents had never consumed iron supplements. After the intervention, the increase in correct answers ranged from 0.8 to 21.9 percent, with the highest rating being on vitamins that help with iron absorption, beverages that inhibit iron absorption and cause anemia. The average score for adolescent knowledge before intervention is 6.46. The average score after intervention increased to 7.27. T-Test results showed significant differences in knowledge scores before and after the intervention. Teenage Health Care Services need to be established as adolescent health counselors so that they can motivate other students in adolescent reproductive health, especially in consuming iron supplements.
\end{abstract}

Keywords: Anemia, Adolescent, Knowledge, Iron Supplement.

\section{A. INTRODUCTION}

Anemia is a nutritional problem that exists when red blood cells lack iron (hemoglobin) (Kementerian Kesehatan Republik Indonesia, 2016). The prevalence of anemia is very high (ranging between $80-90 \%$ ) in preschool children, adolescent girls, pregnant and lactating women (National Nutrition Monitoring Bureau (NNMB), 2006; Park, 2007). Based on the results of basic Health Research (Riskesdas 2013 and 2018) the prevalence of anemia in Indonesia increased from 37.1\% in 2013 (Balitbangkes Kemenkes RI, 2013) to 48.7\% in 2018 (Balitbangkes Kemenkes RI, 2018). Based on Riskesdas 2018, the prevalence of anemia in Riau province is $21.1 \%$. This figure exceeds $20 \%$ as a moderate public health problem (WHO, 2011).

Adolescence is a transitional phrase, with fast growth and strong nutritional needs fulfilled (Singh et al., 2019). Anemia among adolescent girls occurs due to the increased need for iron to compensate for iron loss caused by menstruation(Angrainy et al., 2019), coupled with poor food intake, high infection rates and worm infestations (Kamat \& Sengupta, 2019).

The approach taken to prevent anemia is by giving Iron supplement tablets to junior and high school students. Based on WHO recommendations in 2011, efforts to combat anemia in adolescent girls and adult women concentrate on promotional and 
preventive measures, including iron supplementation, iron-rich food intake, and iron and folic acid fortification of foods (Kementerian Kesehatan Republik Indonesia, 2016). One of the government's programs is to provide iron supplements for teenage girls. Based on the result of Riskesdas (2018), teenage girls who receive an iron supplement are $76.2 \%$ composed of $80.9 \%$ who receive iron supplements at school and $19.1 \%$ who do not receive iron supplements from school. Students who did not obtain any iron supplements were $23.8 \%$. The coverage of iron tablets for young women in the province of Riau is 23.86\%, it has not reached the 2018 Strategic Plan goal of 15\% (Dinas Kesehatan Provinsi Riau, 2018).

Although the government has carried out various programs by providing supplements to meet the iron requirements, the Recommended Dietary Allowances (RDA) for micronutrients are not only met by diet or supplements. Adequate and sustainable improvements in diet and behavior are needed to reduce micronutrient malnutrition (Singh et al., 2019). It is important to determine the level of awareness of adolescents in order to improve intervention strategies so that the interventions being implemented can be sustainable. The prevalence of anemia depends on the knowledge of adolescents about anemia prevention (Kakkar et al., 2010). Therefore, the purpose of this study was to find out the description of adolescent knowledge about anemia and the consumption of iron supplements before and after health education at 16 high school students in Pekanbaru City.

\section{B. METHOD}

This research was a quantitative study with a quasi-experimental design (The One Group Pretest-posttest Design) without control. The treatment given was giving the material in the form of lectures using PowerPoint slides, presenting health posters and playing videos. The data were obtained in January 2020. The sample consists of 119 senior high school students 16 who attended health education. To determine the extent of adolescent knowledge of the information received, questionaires were distributed before and after the information was supplied. The questions on the pre-test questionaire are the same as the questions on the post-test questionnaire. The variables collected were student characteristics and adolescent knowledge. Adolescent knowledge includes causes of anemia, symptoms of anemia, iron-absorbing supplements, iron-inhibiting beverages, and the benefits of blood supplement tablets. The knowledge score is obtained by adding all answered correctly divided by the number of questions on the questionnaire. Univariate and bivariate data analysis was conducted with the T-Test (Paired Samples T-Test) to determine variations in the scores of knowledge before and after the intervention. The T-Test is used for normally distributed data. The Marginal Homogeneity Test was used to determine the differences in each item before and after the education was given. 


\section{RESULT AND DISCUSSION}

\section{Adolescent Characteristics}

Most of the students are female (78.2\%) and most father's education is Senior high school (53.8\%). Likewise with maternal education where the senior high school is the highest percentage (45.4 percent). The father's occupation with the highest percentage is labor $(28.6 \%)$, self-employed $(22.7 \%)$, and private employees $(19.3 \%)$. In general, the work of mothers is housewives (89.1\%). Sociodemographic characteristics of adolescents are presented in Table 1.

Table 1 Sociodemographic Characteristics of Adolescents at 16 Senior High School in Rumbai Pekanbaru in 2020

\begin{tabular}{llcc}
\hline Characteristics & \multicolumn{1}{c}{ Category } & n (119) & o \\
\hline Gender & Female & 93 & 78.2 \\
& Male & 26 & 21.8 \\
Education & Elementary school & 20 & 16.8 \\
& Junior High & 24 & 20.2 \\
& High school & 64 & 53.8 \\
Mother's & University/College & 11 & 9.2 \\
Education & Elementary school & 24 & 20.2 \\
& Junior High & 28 & 23.5 \\
& High school & 54 & 45.4 \\
Father's & University/College & 13 & 10.9 \\
occupation & Government employees & 5 & 4.2 \\
& Private employees & 23 & 19.3 \\
& entrepreneur & 27 & 22.7 \\
& Farmers / Fishermen & 22 & 18.5 \\
& Retired & 8 & 6,7 \\
& Labor & 34 & 28.6 \\
& PNS / TNI / POL Government & 5 & 4.2 \\
Mother's job & employees RI & 2 & 1.7 \\
& Private employees & 6 & 5,0 \\
& entrepreneur & 106 & 89.1 \\
& Housewife & & \\
\hline & & &
\end{tabular}

\section{Take Iron Supplements}

The iron supplement behavior in female students is shown in Figure 1. The female students who have never taken iron tablets are $35.5 \%$. 


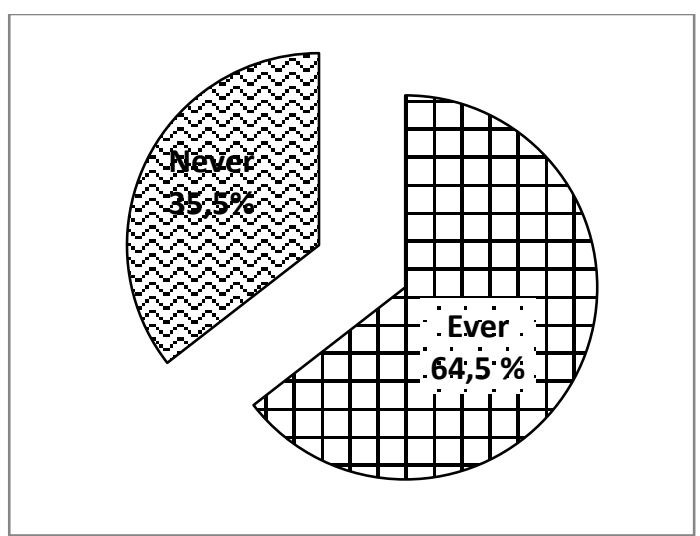

Figure 1 Consumption of Iron Tablets in Female Student at 16 Senior High School Rumbai Pekanbaru in 2020

\section{Adolescent Knowledge}

The results showed that before the intervention, adolescents incorrectly answered certain questions more than 50\% induced anemia (57.1\%), symptoms of anemia which included dizzy eyes $(79.0 \%)$, cold hands and feet $(68.1 \%)$, rapid heart palpitations $(80.7 \%)$, and nausea $(88.2 \%)$. Similarly, the question of vitamins assisting with iron absorption (79.0\%) and beverages inhibiting iron absorption $(63.0 \%)$. After the intervention, the percentage of correct answer ranged from 0.8 to $21.9 \%$ increased. The vitamin that improves iron absorption was the highest percentage increase in the correct answer. The results of the Marginal Homogeneity Test showed that there was a significant difference in adolescent knowledge before and after the intervention ( $\mathrm{p}<$ 0.05), with the exception of questions regarding symptoms of anemia, including dizzy eyes $(p=0.083)$, exhausted and lethargic ( $p=0.083)$ and dizziness (0.317) (Table 2).

Table 2 Pretest and Posttest Results for Anemia Prevention in Adolescents at 16 Senior High School in Rumbai, Pekanbaru City in 2020

\begin{tabular}{|c|c|c|c|c|c|c|c|}
\hline \multirow[b]{2}{*}{ Question } & \multirow[b]{2}{*}{ Category } & \multicolumn{2}{|c|}{ Pretest } & \multicolumn{2}{|c|}{ Posttest } & \multirow{2}{*}{$\begin{array}{c}\text { Difference } \\
(\%)\end{array}$} & \multirow{2}{*}{$\begin{array}{c}\text { Pvalue } \\
\text { (Marginal } \\
\text { Homogenity) }\end{array}$} \\
\hline & & $\begin{array}{c}n \\
(119)\end{array}$ & $\%$ & $\begin{array}{c}n \\
(119)\end{array}$ & $\%$ & & \\
\hline \multirow{2}{*}{ Causes of anemia } & False & 68 & 57.1 & 49 & 41.2 & 15.9 & $<0.001$ \\
\hline & Right & 51 & 42.9 & 70 & 58.8 & & \\
\hline \multicolumn{8}{|l|}{ symptoms of Anemia } \\
\hline \multirow{2}{*}{ Dizzy eyes } & False & 25 & 21.0 & 22 & 18.5 & 2.5 & 0.083 \\
\hline & Right & 94 & 79.0 & 97 & 81.5 & & \\
\hline \multirow{2}{*}{ Cold hands and feet } & False & 81 & 68.1 & 76 & 63.9 & 4.2 & 0.025 \\
\hline & Right & 38 & 31.9 & 43 & 36.1 & & \\
\hline \multirow{2}{*}{ Heart beats fast } & False & 96 & 80.7 & 81 & 68.1 & 12.6 & $<0.001$ \\
\hline & Right & 23 & 19.3 & 38 & 31.9 & & \\
\hline Exhausted and Lethargic & False & 17 & 14.3 & 14 & 11.8 & 2.5 & 0.083 \\
\hline
\end{tabular}




\begin{tabular}{llcccccc} 
& Right & 102 & 85.7 & 104 & 88.2 & & \\
Pale eyelids & False & 53 & 44.5 & 44 & 37.0 & 7.5 & 0.003 \\
& Right & 66 & 55.5 & 75 & 63.0 & & \\
Dizzy & False & 40 & 33.6 & 39 & 32.8 & 0.8 & \\
& Right & 79 & 66.4 & 80 & 67.2 & & $<0.001$ \\
Nausea & False & 105 & 88.2 & 90 & 75.6 & 12.6 & $<0.001$ \\
Vitamins that help & Right & 14 & 11.8 & 28 & 24.4 & & $<0.001$ \\
absorption of Iron & False & 94 & 79.0 & 68 & 57.1 & 21.9 & \\
Beverages which inhibit & Right & 25 & 21.0 & 51 & 42.9 & & 0.014 \\
False & 75 & 63.0 & 56 & 47.1 & 15.9 & \\
Iron supplements are & Right & 44 & 37.0 & 63 & 52.9 & & \\
given to adolescents to & False & 23 & 19.3 & 17 & 14.3 & 5,0 & \\
prevent anemia & Right & 96 & 80.7 & 102 & 85.7 & & \\
\hline
\end{tabular}

\section{The Difference in Knowledge Score before and After the Health Education}

Table 3 shows that there is a significant difference in the knowledge scores of adolescents before and after the intervention (pvalue $<0.001$ ). The difference in score is 1.36 points with a standard deviation of 1.12 points.

Table 3 Adolescent Knowledge Differences Score Before and After of Health Education

\begin{tabular}{lccc}
\hline \multirow{2}{*}{ Health Education } & $\begin{array}{c}\text { Knowledge } \\
\text { Score }\end{array}$ & delta & $\begin{array}{c}\text { Pvalue (Paired Samples } \\
\text { T Test) }\end{array}$ \\
\cline { 2 - 3 } & Mean (SD) & Mean (SD) & \\
\hline Before & $7,80(2,56)$ & $1.36(1.12)$ & $<0.001$ \\
After & $6.44(2.67)$ & & \\
\hline
\end{tabular}

Based on the study results, it was found that $35.5 \%$ of teenage girls never even had iron supplements consumed. Iron supplementation is one of the programs of the government to resolve anemia. The granting of iron tablets is an implementation of the circular letter from the Director General of Public Health, Ministry of Health of the Republic of Indonesia Number HK.03.03 / V/0595/2016 concerning the provision of iron tablets (Kementerian Kesehatan Republik Indonesia, 2016). Global recommendations recommend that for areas with a prevalence of anemia $\geq 40 \%$, giving iron tablets to adolescent girls and women of childbearing age consists of 30-60 mg of elemental iron given every day for 3 consecutive months in 1 year (WHO, 2016). For areas with a prevalence of $20 \%$ anemia, iron supplementation consisting of $60 \mathrm{mg}$ elemental iron and $2.800 \mathrm{mcg}$ folic acid was given for 3 months once a week and the next 3 months were not given (WHO, 2011).

The iron supplement program has been routinely given to female students to consume iron tablets simultaneously. However, the awareness to consume iron tablets 
is still low. This was caused by the discomfort of the students over the effects of iron tablets, which induced nausea. A qualitative study stated that the effects of adolescent girls after consuming iron tablets are nausea, vomiting, and dizziness (Fitriana \& Pramardika, 2019).

Based on the study results, it was found that $18.6 \%$ of adolescents did not know the iron supplements benefits. Adolescent knowledge will create an understanding of the importance of iron supplements being consumed. A number of teenagers also have poor knowlegde of anemia. More than 50\% of adolescents have poor knowledge of anemia (Angadi \& Ranjitha, 2016; Premaletha \& Safeena, 2019). Research Singh et al., found that iron supplements are provided weekly and intensive interventions in health education have an effect on the young women 's knowledge, attitudes, activities and health-seeking behaviors (Singh et al., 2019). Anemia prevention intervention strategies include increasing knowledge among adolescents through health education and iron supplementation programs (Mengistu et al., 2019)

Adolescent knowledge is also still poor about symptoms of anemia. Of the seven signs of anemia identified, the majority of adolescents answered that they were exhausted, exhausted and lethargic. More than 50\% of adolescents lack knowledge of symptoms of anemia (Angadi \& Ranjitha, 2016; Mengistu et al., 2019). Adolescents need to know about the symptoms of anemia in order to predict themselves and take further measures to prevent and treat anemia when anemia occurs.

Adolescent knowledge about vitamins that can help absorb iron is still weak. There was an improvement in knowledge by $21.9 \%$ after the intervention. Research conducted by Kaimudin et al found that $47.2 \%$ of adolescents consumed less Vitamin C. In that study, 55.3\% of adolescents who did not consume Vitamin C had anemia (Kaimudin et al., 2017). Through offering health education in the form of counseling, it is hoped that it will improve understanding and boost adolescent awareness of highvitamin $C$ and iron adolescent diets. Research states that $46 \%$ of adolescents do not know the relationship between vitamin C and iron absorption (Kamat \& Sengupta, 2019).

In addition to the vitamins that help absorb iron, beverages that inhibit iron absorption, namely coffee and tea, have also been questioned. The polyphenols in coffee and tea are the main inhibitors of iron absorption (Marina et al., 2015). Adolescent low knowledge is supported by Kamat and Sengupta research, which states that $46 \%$ of adolescents do not know the relationship between coffee and tea drinking habits that inhibits iron absorption (Kamat \& Sengupta, 2019). Adolescents who usually drink tea are at twice the risk of anemia compared to adolescents who do not drink tea (Fitrianti \& Miko, 2019). Adolescent habits need to be modified, especially younger women who consume tea along with meal times. If adolescents want to consume foods and drinks that inhibit iron absorption, they should consume these foods or drinks two hours 
before or after consuming iron supplements (Kementerian Kesehatan Republik Indonesia, 2016)

Iron supplements to prevent anemia will be successful if adolescents have knowledge of the benefits of iron supplement and the impact it will have if anemia occurs. Knowledge of an object involves two aspects, namely positive and negative. Those two factors will decide the attitude of a person, the more positive aspects of the object that are identified, the more positive the attitude towards a specific object will be (Notoatmodjo, 2014). Iron supplements consumption awareness cannot be separated from the provision of educational and communication information conducted by teachers, health workers and friends. Research conducted by Yusoff et al shows that three-month health education in high school will improve knowledge, attitudes and hemoglobin levels (Yusoff et al., 2012). Likewise, Pardosi's research, by providing booklets on anemia to adolescent girls was effective in increasing knowledge, attitudes and hemoglobin levels (Pardosi, 2019). Health education initiatives are required to raise awareness among young females and to disseminate information about anemia prevention and control (Pareek \& Hafiz, 2015). Intensive health education interventions have an impact on increasing the knowledge, attitudes, practices and health-seeking behavior of adolescents. Schools can be relevant, effective and efficient places to implement comprehensive health educational programs, making it easier to reduce the burden of diseases (Singh et al., 2019).

The results showed that there were significant differences in the knowledge scores of adolescents before and after intervention (pvalue $<0.001$ ). Health education in the form of counseling should be carried out periodically and consistently to further increase student knowledge scores. Research in India found that consumption of iron tablets and health education interventions for school students intensively had an impact on increasing the knowledge, attitudes, practices and behavior of adolescents in healthseeking, especially anemia (Singh et al., 2019).

Health education through counseling can be carried out by empowering adolescents to understand the importance of preventive measures and the steps taken to prevent anemia in adulthood. Training programs should be organized to make adolescents aware of the importance of iron-rich dietary sources for adolescents, and specific issues and information about anemia such as the adverse effects of drinking tea and coffee on reducing iron absorption (Pareek \& Hafiz, 2015). Further research is needed to determine adolescent adherence to the consumption of iron tablets which are routinely given every week by the health center and its effect on preventing anemia in adolescent girls.

\section{CONCLUSION}

Adolescent knowledge on anemia has improved after following health education. A Teenage Health Care Service needs to be set up as a youth health 
counselor so that it can empower other students in adolescent reproductive health, particularly in iron tablet consumption. Further studies are required to determine the adherence level of iron tablets consumed by adolescent girls and their effect on the incidence of anemia in adolescent girls.

\section{ACKNOWLEDGMENT}

Thanks are given to the principal, teachers and students of 16 Senior High school in Pekanbaru City, the leadership and staff of the Karya Wanita Rumbai Community Health centers for facilitating this study. Thank you also to the Hang Tuah Pekanbaru Foundation for funding this activity.

\section{REFERENCES}

1. Angadi, N., \& Ranjitha, A. (2016). Knowledge, attitude, and practice about anemia among adolescent girls in urban slums of Davangere City, Karnataka. International Journal of Medical Science and Public Health, 5(3), 416.

2. Angrainy, R., Fitri, L., \& Wulandari, V. (2019). Pengetahuan Remaja Putri Tentang Konsumsi Tablet Fe Pada Saat Menstruasi Dengan Anemia. Jurnal Endurance : Kajian Ilmiah Problema Kesehatan, 4(2), 343-349.

3. Balitbangkes Kemenkes RI. (2013). Riset Kesehatan Dasar: Riskesdas 2013.

4. Balitbangkes Kemenkes RI. (2018). Laporan Nasional Riskesdas 2018.

5. Dinas Kesehatan Provinsi Riau. (2018). LKjIP Pemerintah Tahun 2018.

6. Fitriana, \& Pramardika, D. D. (2019). Evaluasi Program Tablet Tambah Darah pada Remaja Putri. Media Publikasi Promosi Kesehatan Indonesia, 2(3), 200-207.

7. Fitrianti, L., \& Miko, T. Y. (2019). Factors Associated with Anemia Among Adolescence Girls at SMAN 1 Telukjambe Kabupaten Karawang in 2015. Proceeding The 3rd International Meeting of Public Health, 2019, 454-460.

8. Kaimudin, N. la, Lestari, H., \& Afa, J. R. (2017). Skrining dan Determinan Kejadian Anemia pada Remaja Putri SMA Negeri 3 Kendari Tahun 2017. Jurnal Ilmiah Mahasiswa Kesehatan Masyarakat, 2(6), 1-10.

9. Kakkar, R., Kakkar, M., Kandpal, S. D., \& Jethani, S. (2010). Study of anemia in adolescent school girls of Bhopal. Indian Journal of Community Health, 22(1), 20102012.

10. Kamat, S., \& Sengupta, R. (2019). Nutrition intervention for improvement of knowledge on anaemia prevention among adolescent girls in Mumbai (16-19 years). International Journal of Food and Nutrition, 4(2), 136-139.

11. Kementerian Kesehatan Republik Indonesia. (2016). Pedoman Pencegahan dan Penanggulangan Anemia pada Remaja Putri dan Wanita Usia Subur (WUS).

12. Marina, Indriasari, R., \& Jafar, N. (2015). Konsumsi Tanin dan Fitat Sebagai Determinan Penyebab Anemia pada Remaja Putri di SMA Negeri 10 Makasar. Jurnal MKMI, 6(Maret), 50-58. 
13. Mengistu, G., Azage, M., \& Gutema, H. (2019). Iron Deficiency Anemia among InSchool Adolescent Girls in Rural Area of Bahir Dar City Administration, North West Ethiopia. Hindawi, 2, 1-9.

14. National Nutrition Monitoring Bureau (NNMB). (2006). NNMB Reports 1975-2006.

15. Notoatmodjo, S. (2014). Ilmu Perilaku Kesehatan. Rineka Cipta.

16. Pardosi, M. (2019). The Effectiveness of Booklet of Anemia on the Behaviors of Adolescent Girls. Global Journal of Health Science, 11(10), 111-119.

17. Pareek, P., \& Hafiz, A. (2015). A Study on Anemia Related Knowledge Among Adolescent Girls. International Journal of Nutrition and Food Sciences, 4(3), 273-276.

18. Park, K. (2007). Park'sTextbook of Preventive and Social Medicine 19th.

19. Premaletha, T., \& Safeena, S. (2019). Prevalence of anaemia and knowledge of adolescent girls regarding anaemia. Journal of Paeditiactics and Nursing Science, 2(3), 74-76.

20. Singh, M., Honnakamble, R. A., Rajoura, O. P., \& Singh, M. (2019). Knowledge , Attitude and Practice Change about Anemia after Intensive Health Education among Adolescent School Girls of Delhi: An Intervention Study. International Journal of Medicine and Public Health, 9(3), 71-73.

21. WHO. (2011). Prevention of iron deficiency anaemia in adolescents Role of weekly iron and Folic Acid Supplementation. In World Health Organization. WHO.

22. WHO. (2016). Guideline: Daily iron Supplementation in Adult Women and Adolescent Girls. World Health Organization.

23. Yusoff, H., Daud, W. N. W., \& Ahmad, Z. (2012). Nutrition Education and Knowledge, Attitude and Hemoglobin Status of Malaysian Adolescents. Southeast Asian J Trop Med Public Health, 43(1), 192-200. 